\title{
PETA GERAKAN SYI'AH DI KALIMANTAN SELATAN
}

\author{
Humaidy \\ Fakultas Tarbiyah dan Keguruan IAIN Antasari Banjarmasin \\ Diterima 10 Januari 2014/Disetujui 16 Maret 2014
}

\begin{abstract}
This article traces back the entry of the Shi'a in South Kalimantan through the inclusion of Islamic Wujudiyah (panentheism) Sufism which was first spread in the kingdom of Banjar. This is due to the similarity between Wujudiyah Sufism with the concept of Irfan in Shi'a. However, the influence of Shia in South Kalimantan suffered a setback at the era of Syekh Muhammad al-Banjari Arsyad (1710-1812 AD). According to Habib Ali, Shia began to revive in South Kalimantan after the Iranian revolution in 1979. Ja'fari school of thought (madhabs) is the growing Shiah in South Kalimantan. The Development of Shi'a in South kalimantan faces many challenges since Muslims in South Kalimantan have a strong belief in Sunni.
\end{abstract}

Kata kunci: Syi'ah, Islam Sunni, dan Syi'ah Ja'fariyah.

\section{Pendahuluan}

Syi'ah adalah salah satu sekte atau kelompok Islam yang mempunyai pengikut besar dan tersebar luas di dunia Islam, sesudah sekte atau kelompok Islam Sunni (Ablussunnah wal Jama'ah). Ia merupakan produk sejarah yang lahir dari rahim peradaban Islam yang sah. Keberadaannya tidak bisa dipungkiri, apalagi sampai dinafikan sama sekali. Azyumardi Azra menekankan berkali-kali bahwa kaum Syi'ah adalah saudara kandung kaum Sunni. Lebih jauh lagi, ia menegaskan, kaum Syi'ah adalah bagian hakiki dari Islam. Bersama kaum Sunni, kaum Syi'ah adalah sayap-sayap Islam lainnya. Tentunya, lebih banyak persamaan daripada perbedaan di antara mereka karena keduanya berasal dari sumber yang persis sama, mereka taat kepada ajaran-ajaran yang sama yang berkait dengan iman dan Islam. ${ }^{1}$

1Dicky Sofyan, Peny., Sejarah \& Budaya Syi'ab di Asia Tenggara, Yogyakarta: Sekolah Pascasarjana UGM, 2013, hlm. 5. 
Qurais Syihab menyatakan sejak tahun 1961 di Mesir sudah terdapat fatwa yang terbit dari lembaga Mawsu'ah Jamal Abdul Nashir al-Faqqiya (yakni judul ketika pertama kali terbit) yang di dalamnya tercakup delapan mazhab yang diakui dunia Islam, yakni empat mazhab Sunni yang terkenal (Hanafi, Maliki, Syafi'i dan Hanbali); dua mazhab Syi'ah (Ja'fariyah dan Zaidiyah); dan satu mazhab Khawarij ('Ibadiyah); serta satu mazhab Daud Zahiri (Zahiriyah). Fatwa yang sama muncul dan berlaku pula di negara Turki, Arab Saudi dan Qathar. $^{2}$

Selanjutnya Konferensi Ulama Islam Internasional di Amman, Yordania yang diselengarakan pada tanggal 4-6 Juli 2005 menghasilkan tiga kesepakatan sebagai berikut:

Pertama, siapa saja yang mengikuti dan menganut salah satu dari empat mazhab Sunni (Hanafi, Maliki, Syafi'i dan Hanbali), dua mazhab Syi'ah (Ja'fariyah dan Zaidiyah), mazhab 'Ibadiyah dan mazhab Zahiriyah adalah Muslim. Tidak diperbolehkan mengkafirkan salah seorang dari pengikut/penganut mazhab-mazhab yang disebut di atas. Darah, kehormatan dan harta benda salah seorang dari mereka tidak boleh dihalalkan. Kedua, ada jauh lebih banyak kesamaan dalam delapan mazhab tersebut dibandingkan perbedaan-perbedaan di antara mereka. Para pengikut/penganut delapan mazhab yang telah disebutkan di atas semuanya sepakat dalam prinsip-prinsip utama Islam. Kesemuanya percaya kepada satu Allah Yang Maha Esa dan Maha Kuasa, percaya pada Qur'an sebagai wahyu Allah; dan bahwa Muhammad SAW. adalah Nabi dan Rasul untuk seluruh manusia. Kesemuanya sepakat pada lima rukun Islam, Syahadat, Salat, Zakat, Puasa di bulan Ramadan dan Haji ke Baitullah di Makkah. Kesemuanya sepakat pada enam rukun Iman; kepercayaan pada Allah, para Malaikat-Nya, Kitab-kitab-Nya, para Rasul-Nya, Hari Akhir, dan takdir baik dan buruk dari sisi Allah. Perbedaan di antara ulama kedelapan mazhab, hanya menyangkut masalah-masalah cabang agama (kbilafiyah furu'iyah) dan menyangkut prinsip-prinsip dasar (ushuliyah). Perbedaan pada masalah-masalah cabang agama tersebut adalah rahmat Ilahi. Sejak dahulu dikatakan bahwa keragaman pendapat di antara ulama adalah hal yang baik. Ketiga, mengakui kedelapan mazhab berarti bahwa mengikuti suatu metodologi dasar dalam mengeluarkan fatwa adalah suatu yang absah. Tidak ada orang yang berhak mengeluarkan fatwa tanpa keahlian pribadi khusus

2Tim ABI, Buku Putih Maz̧ab Syi'ah, Jakarta: DPP ABI, 2012, hlm. xix. 
yang telah ditentukan oleh masing-masing mazhab bagi para pengikutnya. Tidak ada orang yang boleh mengeluarkan fatwa tanpa mengikuti metodologi yang telah ditentukan oleh kedelapan mazhab tersebut. Tidak ada orang yang boleh mengklaim untuk melakukan ijtihad mutlak dan menciptakan mazhab baru atau mengeluarkan fatwafatwa yang tidak bisa diterima hingga membawa umat Islam keluar dari prinsip-prinsip agama dan kepastian-kepastian syariah sebagaimana yang telah ditetapkan oleh masing-masing mazhab yang telah disebutkan di atas.

Rekomendasi atau ijma' ulama di tingkat internasional ini ditandatangani oleh 500-an lebih ulama dari berbagai dunia Islam. Penanda tangan dari Indonesia adalah Dr. Hj. Tutty Alawiyah (Rektor Universitas Islam AlSyafi'iyah, Jakarta), Dr. KH. Ahmad Hasyim Muzadi (mantan ketua PBNU), Dr. H. Dien Syamsuddin (Ketua PP. Muhammadiyah) dan Muhammad Iqbal Sullam (Pengurus International Conference of Islamic Scholars). ${ }^{3}$

Pernyataan di atas sengaja ditampilkan pada pendahuluan dari tulisan ini, dalam rangka untuk mensosialisasikan salah satu keputusan besar kesepakatan ulama dunia Islam tentang delapan mazhab yang mungkin belum diketahui oleh banyak umat Islam Indonesia terutama di kalangan masyarakat awamnya. Seraya diiringi dengan pengenalan salah satu mazhab dari delapan mazhab yang diakui tersebut, yaitu Syi'ah.

Umat Islam Indonesia sejak awal kedatangan Islam telah diwarnai oleh paham Syi'ah ini, bahkan ada sebagian sejarawan yang mengatakan Syi'ah lah yang pertama kali masuk sebelum kalangan Sunni. Jika kemudian Sunni yang menjadi mayoritas di negeri ini, bukan berarti Syi'ah tidak berperan sama sekali, justru telah mewarnai dalam keberagamaan masyarakat Indonesia yang berpaham Sunni. Pengaruh Syiah ini dapat dilihat dari paham perseorangan maupun lembaga keagamaan yang berkembang di Indonesia. Seperti ormas NU misalnya, yang dikenal sebagai penganut Sunni yang kuat bahkan fanatik disinyalir Gus Dur banyak mengadopsi kultur Syi'ah dalam penghayatan dan pengamalan keagamaannya, sehingga ia sering menyebut NU sebagai Syi'ah kultural atau Syi'ah tanpa imamah.

Di Kalimantan Selatan yang umat Islamnya sangat kuat bahkan fanatik berpegang teguh terhadap paham Sunni, sebenarnya secara diam-diam gerakan Syi'ah telah berkembang pula. Di sini nanti akan diuraikan bagaimana

${ }^{3}$ Tim Penyusun, Ensiklopedi Islam, jilid I, Jakarta: PT. Ichtiar Baru van Hoeve, 2005, hlm. 2-3. 
perkembangan Syi'ah? Di mana saja pusat-pusat atau wilayah-wilayah yang menjadi lokusnya? Siapa saja tokoh-tokoh pentingnya? Berapa kira-kira jumlah penganut dan pengikutnya? Apa saja kegiatannya? Bagaimana tantangan yang menghadang dinamikanya? Bagaimana responnya terhadap tantangan tersebut?

\section{Metode Penelitian}

Untuk menggali sejumlah pertanyaan di atas, penulis menggunakan; Pertama, metode wawancara mendalam terhadap tokoh-tokoh Syi'ah yang dianggap penting yakni tokoh-tokoh Syi'ah yang mempunyai wawasan luas tentang sejarah perkembangan Syi'ah di daerah ini dan mempunyai jaringan yang kuat dengan tokoh-tokoh lainnya. Kedua, metode observasi sebagai metode yang berfungsi sebagai verifikasi dan komplementasi dari hasil wawancara dengan melakukan pengamatan mendalam pada tempat-tempat tertentu yang dirasa menjadi lokus penting gerakan Syi'ah. Ketiga, metode dokumenter yang berfungsi sebagai penunjang dari hasil wawancara dan observasi.

\section{Mengenal Syi'ah Ja'fariyah}

Sebelum memasuki permasalahan, ada baiknya diperkenalkan terlebih dahulu tentang Syi'ah Ja'fariyah. Syi'ah Jafariyah disebut pula Syi'ah Imamiyah Itsna 'Asyariyah (Syi'ah Dua Belas Imam), karena mereka punya doktrin tentang imam yang jumlahnya sebanyak dua belas orang. Sekte ini meyakini bahwa Nabi Muhammad Saw telah menetapkan dua belas orang imam sebagai penerus risalah beliau. Mereka mempercayai bahwa imam itu ma'shum. Apa yang dikatakan dan dilakukan mereka tidak akan bertentangan dengan kebenaran karena mereka dijaga oleh Allah Swt dari perbuatan salah dan kelupaan. ${ }^{4}$ Dengan demikian imam-imam itu dipercayai sebagai manusia tanpa dosa. ${ }^{5}$

Nama-nama imam yang berjumlah dua belas orang itu adalah Ali bin Abi Thalib (Amirul Mukminin), Hasan bin Ali (Mujtaba), Husein bin Ali (Sayyidus Syubada), Ali bin Husein Zainal Abidin (Sajjad), Muhammad bin Ali al-Baqir (Abdus Syakur), Ja'far bin Muhammad as- Shadiq (Qaim), Musa bin Ja'far alKazhim (Abdus Shaleb), Ali bin Musa ar-Ridla (Nurul Hidayah), Muhammad bin

${ }^{4}$ Tim Penyusun, Ensiklopedi Islam, jilid I, Jakarta: PT. Ichtiar Baru van Hoeve, 2005, hlm. 316.

${ }^{5}$ Hadariansyah, Pemikiran-Pemikiran Teologi, Dalam Sejarah Pemikiran Islam, Banjarmasin: Antasari Press, 2013, hlm. 46. 
Ali al-Jawad (Taqiy), Ali bin Muhammad al-Hadi (Naqiy), Hasan bin Ali alAskari (Syafiy), dan Muhammad bin Hasan al-Muntazhar (Mahdi). ${ }^{6}$

Menurut Syi'ah Imamiyah Itsna 'Asyariyah, jabatan imamah berakhir pada Imam Muhammad al-Muntazhar. Imam terakhir ini disebut juga sebagai dengan Imam Al-Mahdi. Sesudah imam tersebut, tidak ada lagi imam sampai hari kiamat. Imam Muhammad al-Muntazhar yang terkenal pula sebagai Imam Mahdi ini diyakini belum mati sampai sekarang. Imam Mahdi masih hidup, tetapi tidak dapat dijangkau oleh orang banyak. Diyakini bahwa sementara ini ia ghaib (bersembunyi), dan di akhir zaman nanti ia akan muncul kembali.

Terhentinya rangkaian imam-imam pada Muhammad al-Muntazhar ini disebabkan ia tidak meninggalkan keturunan. Muhammad, sewaktu masih kecil, hilang di dalam gua yang terdapat di Masjid Samarra (Irak). Menurut keyakinan Syi'ah Imamiyah Itsna 'Asyariyah, Imam ini menghilang buat sementara dan akan kembali lagi sebagai Imam Mahdi untuk langsung memimpin umat Islam. Oleh karena itu, ia disebut imam mustatir (imam yang tersembunyi) atau imam munta:̧̧ar (imam yang dinanti). Selama masih bersembunyi ia memimpin umat Islam melalui raja-raja yang memegang kekuasaan dan ulama-ulama mujtahid Syi'ah. $^{7}$

Muncul pertanyaan mengapa Syi'ah Imamiyah Itsna 'Asyariyah dikenal sebagai Syi'ah Ja’fariyah? Jawabnya, karena dinisbatkan kepada Ja’far bin Muhammad bin Ali bin Husein bin Ali bin Abi Thalib, suami Fatimah AzZahra bin Nabi Muhammad SAW. Ia adalah Imam ke-6 dalam keyakinan kaum Syi'ah Imamiyah Itsna 'Asyariyah. Imam Ja'far Shadiq dilahirkan pada 17 Rabi'ul Awwal (80H/699M) di Madinah. Ibunya bernama Farwah binti Qasim bin Muhammad bin Abu Bakar As-Shiddiq RA. ${ }^{8}$

Imam Ja'far Shadiq adalah seorang ulama besar dalam banyak bidang ilmu, seperti ilmu fikih, filsafat, tasawuf, kimia dan ilmu kedokteran. Para jumhur ulama berpendapat bahwa Imam Ja'far Shadiq adalah seorang mujtahid di dalam ilmu fikih, guru dari Imam Hanafi dan Imam Maliki. Di dunia filsafat Islam, ia terkenal sebagai filosof besar, menjadi guru dari Washil bin Atha', tokoh pendiri aliran teologi Mu'tazilah yang terkenal sebagai kaum rasionalis muslim.

${ }^{6}$ Muhammad Husain Adib, Sekilas Mengenal Empat Belas Ma'sum, Qum, Iran: Yayasan Imam Ali as, 1973, hlm. 8-25.

${ }^{7}$ Nasution, Harun, Teologi Islam, Jakarta: UI-Press, 1986, hlm. 99.

${ }^{8}$ Ali Muhammad Ali Ad-Dakhil, Aimmatuna, Beirut Lebanon: Dar al-Murtadla, 1982, hlm. 428. 
Di kalangan kaum sufi, ia adalah, Syekh maha guru dan salah satu mata rantai penting dari silsilah hampir seluruh tarekat mu'tabarah. Sementara di kalangan ahli kimia, ia dianggap sebagai pelopor ilmu kimia dalam peradaban Islam, salah seorang muridnya adalah Jabir bin Hayyan, ahli kimia dan kedokteran Islam. Dalam tradisi fikih Syi'ah, Imam Ja'far Shadiq dapat disebut sebagai Bapak Fikih Syiah, karena sebagian besar masalah fikih yang dibahas dalam fikih Syi'ah bersumber atau mencerminkan pandangan-pandangannya. ${ }^{9}$ Hal ini, karena Imam Ja'far Shadiq saja yang paling banyak mendapat kesempatan untuk membimbing umat Islam terutama kaum Syi'ah, para imam yang lain jika tidak kena tahanan rumah, mereka dibatasi ruang geraknya untuk berhubungan dengan kaum muslim. Sementara, pada masa Ja'far Shadiq, para penguasa Bani Umayyah sibuk menghadapi berbagai pemberontakan dan Bani Abbasyiyah yang muncul sesudahnya, lebih banyak memusatkan perhatian untuk memperkuat kekuasaan mereka yang masih baru, maka kesimpulan catatan tentang kata dan prilaku imam itu, didominasi oleh pernyataanpernyataan dan pandangan-pandangan Imam Ja'far Shadiq.

Bagi Syi'ah pintu ijtihad tak pernah tertutup, ulama-ulama mujtahid Syi'ah sejak sesudah Imam ke 12 sampai kini, bebas mempraktikkan jjtibad. Teori-teori baru, sesuai dengan perkembangan zaman dan pemikiran selalu muncul.

Akhir-akhir ini, misalnya dunia dikejutkan oleh teori politik wilayatul faqib yang dikembangka oleh Imam Ayatullah Ruhullah Khumaini sebagai tawaran politik alternatif. Terlepas dari setuju atau tidak setuju terhadap teori ini, munculnya teori brillian ini sendiri dari orang yang dipandang oleh kaum intelektual sebagai kaum tradisional menunjukkan adanya dinamika perkembangan yang pesat dalam dunia Syi'ah. ${ }^{10}$

Namun dalam Syi'ah, tidak boleh juga sembarang orang melakukan ijtihad. Ijtihad boleh dilakukan oleh siapa saja asal memenuhi syarat sebagai mujtahid. Ulama Ja'fari mewajibkan bagi orang awam bertaklid atau merujuk kepada ahlinya. Dalam urusan agama kaum awam harus merujuk kepada para Faqih atau seorang Mujtahid yang memenuhi syarat, yang antara lain; seseorang yang masih hidup, diakui kemampuan dan kredibilitas ijtihadnya, adil, 'abid, takwa, wara', istiqamah, tidak cinta dunia dan tidak melakukan dosa baik. besar maupun kecil.

${ }^{9}$ Muhammad Jawad Mughniyah, Fiqh al-Imam Ja'far al-Shadiq, Beirut: Dar alIlmi li al-Malayin, 1966, hlm. 23.

${ }^{10}$ Busyairi Ali, Nikah Mut'ah, Halal atau Haram, Banjarmasin: Ar-Risalah Islamic Centre Foundation, 2012, hlm. 38. 
Syarat taklid kepada mujtahid hidup ini menuntut adanya orang-orang atau institusi yang terus-menerus memproduksi mengenai kebutuhan taklid ini. Dari sini, lalu lahirlah apa yang kemudian popular dengan istilah marja'iyyah. Ulama-ulama yang dipilih oleh masyarakat sebagai tempat bertaklid atau berittiba' ini disebut marja ${ }^{11}$ Contoh untuk sekarang yang bisa menjadi marja' salah satunya adalah Imam Ali Khamenei yang berada di Iran.

Secara tradisional, para marja' ini langsung atau tidak langsung, memiliki seperangkat tuntunan kehidupan beragama bagi para penganutnya, yang merupakan hasil ijtihadnya pada pelbagai sisi kehidupan, dari persoalan ibadah mabdlah sampai persoalan siyasah (politik). Seperangkat tuntunan beragama ini disebut sebagai Risalah Amaliyah. Para mukallid atau penganut pandangan sang marja', biasanya, selain bertanya langsung kepada sang marja' atau wakilnya dalam urusan agama yang mereka hadapi, akan merujuk ke Risalah Amaliyah yang dihimpun sang marja'.

Contoh praktik ibadah khas Syi'ah Ja'fariyah yang berbeda dengan kaum Sunni adalah dalam salat ketika berdiri betul tidak bersedekap sebagaimana kaum Sunni, saat sujud diletakkan bungkusan tanah (terutama tanah Karbala) pada tempat sujudnya; dalam puasa Ramadlan ketika musafir mereka wajib berbuka sedangkan bagi Sunni boleh terus puasa boleh juga berbuka; dalam perkara hewan yang hidup di air mereka mengharamkan jenis ikan yang tidak bersisik seperti lele, patin, baung, sembilang, telan dan lain-lain, sedang Sunni menghalalkannya; dalam soal nikah Mut'ah mereka menghalalkannya, tetapi Sunni mengharamkannya; dan dalam masalah air mani bagi mereka najis, sementara Sunni menganggapnya suci.

\section{Sejarah Syi'ah di Kalimantan Selatan}

Menurut Habib Ali, Syi'ah secara kultural datang ke Kalimantan Selatan beriringan dengan masuknya Islam di kawasan ini. Di Kalimantan Selatan, Islam datang pada masa jauh lebih belakangan daripada Sumatera dan Jawa. Diperkirakan telah ada sejumlah muslim di wilayah ini sekitar pertengahan abad ke-15, tepatnya 1475-1500 M. Oleh karenanya, Hafiz menjelaskan kemungkinan Islam telah masuk ke sini di masa itu melalui putera Raja Dipa, Raden Sekar Sungsang. Dia melarikan diri ke Jawa setelah dipukul ibunya, Puteri Kabuwaringin yang dikenal pula dengan nama Puteri Kalungsu. Sekar Sungsang kemudian menikah dengan anak Juragan Petinggi yang telah

${ }^{11}$ Imam Khumaini, Al-Ahkam al-Muyassarah, Qum Iran: Dar al-Tiyar al-Jadid, 1982, hlm. 1316. 
mengasuhnya dan mempunyai putera yang diberi nama Raden Panji Sekar. Anaknya itulah yang kemudian menjadi murid sekaligus diambil menantu oleh Sunan Giri dan diberi gelar Sunan Serabut. Beberapa tahun kemudian, Raden Sekar Sungsang pulang ke Negara Dipa dan diangkat menjadi raja dengan gelar Sari Kaburangan. ${ }^{12}$

Tampaknya, anak Sekar Sungsang yang berguru dan sekaligus menantu Sunan Giri dapat dijadikan bukti bahwa Sekar Sungsang sebagai besan Sunan Giri telah menjadi muslim sebelum ia kembali ke Negara Dipa. Selain itu, Hafiz juga mensinyalir bahwa Islam telah masuk ke Negara Dipa melalui saudagar Arab, Keling, Gujarat, Persia, Cina, Melayu dan Bugis. Namun, Islam mencapai kemajuan pesat setelah berdirinya Kesultanan Banjar. Hal tersebut tidak terlepas dari bantuan Kesultanan Demak kepada Pangeran Samudera dalam perjuangan melawan pamannya sendiri Pangeran barunya Sultan Suriansyah atau Raja Suryanullah atau Pangeran Maruhum pada sekitar tahun 1526M dan diangkat sebagai sultan pertama di Kerajaan Banjar. ${ }^{13}$ Oleh karena itu, dalam Hikayat Banjar disebutkan bahwa Kerajaan Demak di Jawa adalah pihak yang berperan besar dalam mengislamkan daerah Banjar. ${ }^{14}$ yang mempunyai wilayah kekuasaan meliputi Tabalong, Barito, Alai, Hamandit, Balangan, Kintap, Biaju Besar, Biaju Kecil, Sebangau, Mendawai, Katingan, Sampit dan Pambuang, di mana bertakluk pula Sukadana, Sanggau, Sambas, Batang Luwai, Karasikan, Kotawaringin, Paser, Kutai dan Berau. Kesemuanya ini meliputi sebagian daerah Kalimantan Barat, Kalimantan Timur, Kalimantan Tengah dengan pusat pemerintahannya berada di Kalimantan Selatan.

Dalam catatan sejarah Banjar, ajaran tasawuf wujudiyah yang pertama kali tersebar bahkan sempat menjadi ajaran resmi Kerajaan Banjar. Ini dibuktikan dengan adanya cap kerajaan yang berbentuk segi empat, di tengahtengah tersusun angka Arab (angka-angka ini dianggap mempunyai kekuatan gaib, sebagaimana cap kerajaan di Persia). Di samping bawah cap tertulis kalimat La Ilaba Illallah, Allah Manjud. Kalimat tersebut biasanya dipergunakan

${ }^{12} \mathrm{~A}$. Hafiz Anshary, Islam di Selatan Borneo sebelum Kerajaan Banjar, Orasi Ilmiah, Banjarmasin: IAIN Antasari, 2002, hlm. 15. 251.

${ }^{13}$ Azyumardi Azra, Jaringan Ulama Nusantara, Bandung: Mizan, 1994, hlm.

${ }^{14} \mathrm{~J} . J$. Ras, Hikajat Bandjar; A Study in Malay Historiography, The Hague: Martinus Nijhoff, 1968, hlm. 107-109. 
oleh sebagian pengikut aliran tasawuf wujudiyah. ${ }^{15}$ Diperkirakan aliran ini tersebar karena adanya sebuah risalah yang sangat populer yakni al-Tubfah al-Mursalab ila Rub an-Nabi karya Fadlullah al-Burhanpuri di kalangan pelajar dan masyarakat pada umumnya sebagai pelajaran dasar di kawasan Nusantara termasuk Kalimantan Selatan. ${ }^{16}$ Di samping itu, karya-karya Hamzah Fansuri, Syamsuddin Sumatrani dan Abdurrauf Singkel (terkenal sebagai Syiah Kuala) dari Aceh yang ajarannya kental dengan nuansa wujudiyah banyak juga dibaca dan dihayati oleh masyarakat Banjar. Oleh karena pada waktu itu hubungan Kerajaan Banjar dengan Kesultanan Aceh sangat erat terutama dalam konteks hubungan intelektual dan kultural. Lebih dari itu, Idwar Saleh mengatakan, konon ada seorang ulama yang hidup dalam Kerajaan Banjar, telah menyusun sebuah buku tasawuf yang bernuansa wujudiyah, berbicara tentang Asal Kejadian Nur Muhammad yang sangat dipengaruhi ajaran Wihdatul Wujud Ibnu Arabi. ${ }^{17}$ Zafri Zamzam menyebut pengarang buku tersebut adalah Syekh Syamsuddin al-Banjari yang ditulis sekitar tahun 1668M, untuk dipersembahkan kepada Sultanat Tajul Alam Syafiatuddin yang memerintah Kesultanan Aceh (1641-1675M), seorang Ratu yang sangat loyal terhadap ajaran tasawuf Wujudiyah. ${ }^{18}$

Dalam tengarai Habib Ali al-Habsyi, tasawuf yang bernuansa wujudiyah ini ada kesamaan dengan konsep Irfan dalam Syi'ah. Apalagi tokoh-tokoh yang berpengaruh dalam mengajarkan doktrin ini seperti Hamzah Fansuri, Syamsuddin Sumatrani dan Abdurrauf Singkel (Syi'ah Kuala) memang menurut Ali Hasymi sebagai tokoh-tokoh dari aliran Syi'ah. Namun, Syi'ah yang tadinya cukup besar, mengalami kemunduran ketika Syekh Muhammad Arsyad alBanjari (1710-1812M) kembali ke kampung halaman dari di Haramain, setelah tiga puluh tahun menuntut ilmu di sana. Hal ini terjadi karena Syekh Muhammad Arsyad al-Banjari sangat gencar mengajarkan Islam dari aliran Sunni. Meskipun begitu, masih banyak kultur-kultur Syi'ah yang merasuk ke dalam kultur Sunni yang menjadi anutan kebanyakan masyarakat Banjar. Tentu saja sudah bukan bentuk asli, melainkan sudah mengalami modikasi, seperti

${ }^{15}$ Ahmadi Isa,"Perkembangan Tasawuf di Kalimantan Selatan", tabloid Serambi Ummah No.045, 8-14 September 2000, hlm. 10.

${ }^{16}$ Azyumardi Azra,"'Interaksi dan Akomadasi Islam dengan Budaya Melayu Kalimantan", makalah Simposium Nasional, 1996, hlm. 120.

${ }^{17}$ Idwar Saleh, Bandjarmasin, Banjarbaru: Unlam, 1982, hlm. 30.

${ }^{18}$ Gazali Usman, Kerajaan Banjar, Sejarah Perkembangan Politik, Ekonomi, Perdagangan dan Agama, Banjarbaru: Unlam Press, 1998, hlm. 130. 
peringatan hari 10 Mubarram (Asyura), bacaan Tulak Bala, Tawassul, Ziarah Kubur, Maulid Nabi dan Arba Mustamir.

Syi'ah mulai menggeliat lagi di Kalimantan Selatan menurut Habib Ali sejak pasca revolusi Iran tahun 1979. Lewat berita-berita yang dipublikasikan baik oleh media cetak (Surat Kabar, Majalah, Tabloid dll) maupun elektronik (Radio dan Televisi) tentang kemenangan Ayatullah Ruhullah Khumaini atas raja Shah Reza Pahlevi yang didukung oleh Amerika Serikat, jelas merupakan api semangat bagi sebuah kebangkitan kembali. Syi’ah menjadi perhatian dunia Islam pada umumnya dan umat Islam Indonesia pada khususnya, untuk mempelajari ajarannya, termasuk anak muda Kalimantan Selatan.

Habib Ali menceriterakan pola penyebaran Syi'ah ini di Kalimantan Selatan sebagai berikut :

\section{Banjarmasin}

Banjarmasin adalah ibukota lama dari provinsi Kalimantan Selatan dan merupakan kota dagang yang penduduknya terpadat di Kalimantan Selatan bahkan Kalimantan. Sebenarnya sebelum revolusi Iran di Banjarmasin sudah dan masih ada sisa-sisa penganut Syi'ah lama, tetapi sangat sedikit dan itupun hanya di kalangan sebagian Ahlul Bait (keluarga Nabi Muhammad Saw) saja dengan belajar secara sembunyi-sembunyi di dalam lingkungan keluarga yang sangat terbatas. Memang baru pasca revolusi Iranlah mereka mulai berani menampakkan diri dan menunjukkan eksistensinya. Pada waktu itu, semarak kajian-kajian intelektual Syi'ah dilakukan di berbagai kelompok diskusi dan LSM terutama oleh dosen muda dan mahasiswa Unlam (Universitas Lambung Mangkurat) Banjarmasin yang membawahi Fakultas Hukum, Kedokteran, Ekonomi, Sosial-Politik dan Ilmu Pendidikan, yang dihadiri mahasiswamahasiswa perguruan tinggi lain dengan mengundang narasumber sesekali dari tokoh Syi'ah sendiri yang berasal dari Jawa. Dari forum inilah akhirnya melahirkan tokoh-tokoh muda energik sebagai intelektual sekaligus aktivis Syi'ah sebut saja umpama Wahyudiannoor SH dan Habib Ali al-Habsyi SE. Setelah terus berjalan secara rutin pada tahun 2008 muncullah majlis Syi'ah yang terbuka untuk umum bernama Majlis Pencinta Ablul Bait dan Yayasan Amanah yang dipimpin oleh Habib Sulaiman al-Idrus.

Habib Sulaiman al-Idrus adalah ulama besar berpengaruh di Banjarmasin, terutama di Kampung Sungai Mesa yang dulu pernah menjadi basis NU di Banjarmasin. Ia salah seorang pengurus ABI (Ablul Bait Indonesia) wilayah Kalimantan Selatan dan merupakan alumni pondok pesantren YAPI 
Bangil yang banyak melahirkan tokoh-tokoh Syi'ah Kalimantan bahkan Indonesia.

Majlis Pencinta Ahlul Bait dan Yayasan Amanah beralamat di Jl. Pahlawan, Kampung Sungai Mesa, di belakang Langgar Hinduwan yang didirikan oleh Habib Abubakar al-Habsyi (almarhum), seorang Habib yang paling dihormati di Banjarmasin. Awalnya majlis ini hanya dihadiri antara 10-20 orang, kini sudah mencapai ratusan orang lebih.

Kegiatan majlis ini, selain pengajian umum yang biasanya bermaterikan akhlak Rasulullah dan keutamaan-keutamaannya, juga melaksanakan amalan rutin ritual Syi'ah seminggu 2 kali, malam Rabu dan malam Jum'at berisi bacaan-bacaan pujian kepada Rasulullah dan Ahlul Bait, juga do'a-do'a terutama do'a Kumail dan do'a Jabsyan Kabir.

Kemudian tidak terlalu berselang lama dari berdirinya Majlis Pencinta Ahlul Bait dan Yayasan Amanah, sekitar tahun 1998 berdiri pula Yayasan ArRisalab di Jalan Sultan Adam oleh H. Busyairi Ali salah seorang mantan aktivis NII yang kemudian tertarik kepada ajaran Syi'ah. Sebenarnya yayasan ini tidak murni milik Syi'ah karena ketika proses berdirinya Busyairi masih berstatus sebagai pengurus Muhammadiyah, bahkan sampai sekarang masih dianggap bagian dari Muhammadiyah meskipun ia sudah menjadi Syi'ah. Kemudian, pada tahun 2008, Busyairi mendirikan lagi Majlis Ta'lim Al-Mukblisin.

Yayasan dan majlis ini cukup banyak fungsi dan kegiatannya, mulai sebagai pondok pesantren yang menampung dan mendidik hampir 50 orang anak, sebagai forum untuk kajian rutin literatur-literatur Syi'ah bagi yang berminat terutama kalangan mahasiswa, termasuk sekaligus konsultasi keagamaan dan menjawab pertanyaan-pertanyaan seputar Syi'ah, sebagai wadah mengadakan seminar, diskusi, lokakarya baik bagi kalangan sendiri maupun orang lain, sebagai majlis pengajian yang dihadiri ratusan lebih jamaah dan pelaksanaan amalan rutin ritual Syi'ah seminggu 2 kali, malam Rabu dan malam Jum'at yang bersamaan dengan Majlis Pencinta Ahlul Bait Sungai Mesa, juga sebagai studio publikasi Syi'ah Kalimantan Selatan dari bahan cetak berupa lembaran sampai buku, dari spanduk sampai promosi di internet. Salah satu buku yang diterbitkan yayasan ini adalah "Nikah Mut'ah" yang ditulis oleh Busyairi sendiri dari tesis S2-nya di Pascasarjana IAIN Antasari Banjarmasin. Dalam buku tersebut ia memperkenalkan siapa itu Imam Ja'far Shadiq, keluasan pikirannya yang mencakup ilmu kalam (teologi), hukum (fiqih) dan irfan (tasawuf), dan cara-caranya melakukan istinbat hukum atas berbagai 
perkara termasuk tentang nikah mut'ah yang menjadi pokok dan fokus pembahasan.

Yayasan dan majlis ini beralamat di Jl. Sultan Adam, Komplek Bumi Graha Lestari Rt. 48, No. 41, Banjarmasin, wilayah baru pengembangan Kota Banjarmasin, berdekatan dengan beberapa kampus baik negeri maupun swasta. Ia berjarak sekitar 600 meter dari kampus Unlam (Universitas Lambung Mangkurat), yang membawahi Fakultas Hukum, Kedokteran, Ekonomi, SosialPolitik dan Ilmu Pendidikan, Uniska (Universitas Islam Kalimantan) dan STIE (Sekolah Tinggi Ilmu Ekonomi). Ia dekat antara 300m dengan STIHSA (Sekolah Tinggi Ilmu Hukum Sultan Adam), Universitas Terbuka, STIKIP (Sekolah Tinggi Ilmu Keguruan dan Ilmu Pendidikan) dan STIMIK (Sekolah Tinggi Ilmu Komputer). Hal ini, membuat Sultan Adam dipenuhi oleh penginapan mahasiswa dari berbagai perguruan tinggi dan beragam latar belakang daerah.

\section{Banjarbaru}

Banjarbaru berjarak sekitar $27 \mathrm{Km}$ dari Banjarmasin, yang merupakan ibukota baru dari Kalimantan Selatan. Di sini terdapat Majlis tak bernama yang dipimpin oleh Habib Abdullah al-Habsyi, selaku Ketua ABI wilayah Kalimantan Selatan. Ia pernah menuntut ilmu di pondok pesantren YAPI sampai selesai. Ia salah satu Habib dan Ulama terkenal di Kalimantan Selatan, khususnya Martapura dan Banjarbaru yang majlisnya dihadiri ratusan orang lebih dari Banjarbaru dan Martapura. Ia juga menjadi tempat bertanya para pengikut Syi'ah di sana bahkan dari seluruh daerah Kalimantan Selatan.

Kegiatan majlisnya, selain pengajian umum yang didatangi berbagai kalangan termasuk dari anggota Syi'ah sendiri, juga melaksanakan amalan rutin ritual Syi'ah 2 kali seminggu, malam Rabu dan malam Jum'at dari jamaah Syi'ah Banjarbaru dan Martapura. ${ }^{19}$

\section{Martapura}

Daerah Martapura sekitar $40 \mathrm{Km}$ dari Banjarmasin, yang terkenal sebagai kota Serambi Mekkah. Disebut Serambi Mekkah karena daerah ini pernah menjadi pusat keilmuan Islam pada akhir abad ke-18 sampai awal abad ke 19 bersama-sama Palembang dan Pattani (Thailand Selatan). Di sini, dari dulu sampai sekarang menjadi basis keagamaan Kaum Tuha (NU) yang banyak melahirkan ulama-ulama besar. Salah satu pentolan Syi'ah di daerah ini adalah Habib Ali al-Habsyi SE. Ia juga termasuk salah satu pengurus ABI wilayah Kalimantan Selatan. Ia dahulu, pada mulanya bukan penganut Syi'ah, 
melainkan berasal dari penganut Sunni jua. Ia mengaku mulai pertama tertarik dengan Syiah, ketika masih remaja saat menjadi Ketua Remaja Masjid dari Masjid Raya Sabilal Muhtadin, Banjarmasin. Ketertarikannya semakin kuat, tatkala ia menjadi mahasiswa Fakultas Ekonomi Unlam dengan membaca banyak buku-buku Syi'ah dan para penulis yang apresiatif terhadap Syi'ah seperti karya-karya Haidar Bagir, Jalaluddin Rahmat, Ali Syariati, SH. Nasr, Murtada Mutahhari, Thabathaba'i dan lain-lain. Ketika ia sudah yakin untuk memilih Syi'ah sebagai keyakinannya, maka semakin intens saja ia mempelajari ajaran-ajaran Syi'ah terutama seluruh pemikiran Ayatullah Ruhullah Khumaini yang menjadi marja'nya. Keseriusannya itu tampak pada upayanya untuk mengakses seluruh buah pikiran Khumaini dalam bentuk apapun, bahkan demi untuk kedekatan dengan idolanya itu, tampak pada dinding rumahnya di ruang tamu banyak terpampang tokoh-tokoh Syi'ah terutama Khumaini. ${ }^{20}$

Pada sekitar tahun 2000-an, ia dan kawan-kawan sempat mendirikan Yayasan Ar-Ridha di Jalan Pendidikan, Sekumpul, Martapura yang sekarang menjadi rumah kediamannya. Melalui yayasan ini telah dibangun sebuah perpustakaan yang banyak menyediakan buku-buku bacaan yang berisi ajaran Syi'ah atas sumbangan kedutaan Iran, Jakarta, Penerbit Mizan dan Yayasan Mutahhari, Bandung dan perorangan dari anggota Syi'ah. Perpustakaan ini dulu, banyak dikunjungi oleh para mahasiwa Unlam Banjarbaru, terdiri dari Fakultas Pertanian, Perikanan, Kehutanan, Mipa, Matematika, InformatikaKomputer, Komunikasi dan Psikologi, dan para santri pondok pesantrenpondok pesantren yang ada di seputar Martapura. Para mahasiswa dan santri tersebut tidak sekadar membaca literatur-literatur Syi'ah yang ada, tetapi juga ada yang bertanya dan mengajak Habib Ali diskusi tentang seluk-beluk ajaran Syi'ah. Namun sayang, tak berapa lama yayasan ini bubar dan tak pernah bangkit kembali.

Habib Ali di Martapura bisa diterima oleh berbagai kalangan sehingga ia bisa masuk kemana-mana dan mudah bergaul kepada siapapun. Di samping, ia dikenal sebagai intelektual dan aktivis muda Syi'ah, ia aktif juga di berbagai Lembaga Swadaya Masyarakat (LSM) seperti Walhi (Wahana Lingkungan Hidup), Forlog (Forum Dialog Antar Agama), Cakrawala Hijau dan LK3 (Lembaga Kajian Keislaman Kemasyarakatan). Ia sering diminta menjadi narasumber dalam berbagai seminar terutama ekonomi baik tingkat lokal, nasional maupun regional. Ia juga sering diminta menjadi fasilitator dalam pelatihan pemberdayaan ekonomi dan koperasi di beberapa lembaga ekonomi

20Wawancara dengan Habib Ali 15 Maret 2014. 
dan pondok pesantren. Tidak hanya sampai di situ, pada tahun 2005 ia dengan niat tulus dan semangat pemberdayaan ekonomi umat, mendirikan BMT Absanu Amala secara sederhana di Jl. A. Yani Km.45 Martapura bersama rekanannya membidik peredaran uang dan membudayakan menabung bagi masyarakat di sini terutama kaum ibu-ibu majlis ta'lim. Kini bangunan BMTnya sudah cukup megah dengan omset mencapai milyaran lebih dari nasabah yang berjumlah ribuan lebih. Sementara di rumahnya sendiri di Jl. Pendidikan, Sekumpul, Martapura, Habib Ali juga menampung 30-an lebih anak jalanan untuk dibina dan diberdayakannya. Di depan rumahnya, ia bangun semacam balai atau pendopo untuk tempat diskusi bebas anak-anak binaannya untuk merumuskan bersama program-program yang harus dijalankan sehari-hari. Selain itu, ia juga menyisihkan sebagian rezekinya setiap bulan dengan memberikan santunan 50-an Syarifah yang berstatus janda dan sudah tua dengan sembako yang diperkirakan cukup untuk satu bulan. Mungkin dari sejumlah kerja pemberdayaan itu, dua tahun yang lalu Ma'arif Institute memberikan penghargaan Ma'arif Award kepadanya. ${ }^{21}$

\section{Rantau}

Rantau merupakan ibukota Kabupaten Tapin yang berjarak sekitar 85 $\mathrm{Km}$ dari Banjarmasin. Di sini, dikenal sebagai kota para Datu, karena demikian banyaknya makam keramat dari para ulama masa lalu. Syi'ah bertumbuh juga di sini, bahkan melahirkan tokoh besarnya yakni Habib Husein al-Habsyi yang sangat berpengaruh dan paling kharismatis, tidak saja pada tingkat lokal, Rantau, tetapi juga tingkat provinsial Kalimantan Selatan, bahkan tingkat regional Kalimantan. Tidak terbatas pada kalangan Syi'ah, tetapi juga meliputi kalangan Sunni. Di daerahnya, ia dipanggil sebagai Habib Tuha (Habib Sepuh) yang sangat disegani dan dihormati oleh masyarakatnya. ${ }^{22}$ Karena di samping ilmu agama, ia hebat juga ilmu batin dan kanuragannya.Hal ini bisa dilihat dari banyaknya tamu dari berbagai kalangan dan tempat jauh (seperti dari Kalimantan Tengah, Kalimantan Timur dan Kalimantan Barat) pula yang datang berkunjung ke tempatnya di desa Mandarahan, belakang Pasar Rantau lama, di Rantau yang demikian jauh dari pusat keramaian kota. Meskipun majlisnya hanya dihadiri sedikit jama'ah, antara 10-40 an, tetapi dipuji sebagai majlis yang berkualitas, terutama yang dilaksanakan pada waktu tengah

${ }^{21}$ Wawancara dengan Habib Ali, 20 Maret 2014.

${ }^{22}$ Tim Peneliti F. Syari'ah, Gerakan Syi'ah di Kalimantan Selatan, Banjarmasin: Puslit IAIN Antasari, 2001, hlm. 8. 
malam. ${ }^{23}$ Karena ia memang tidak dikenal sebagai da'i kondang yang pintar berpidato, melainkan seorang yang sangat baik dan merdu dalam membawakan atau membacakan syair-syair Maulid Nabi Muhammad Saw. ${ }^{24}$ Ia alumni pondok pesantren YAPI Bangil dan pernah juga menjadi pengusaha kayu yang sukses. Sekarang ia adalah salah seorang dewan pembina ABI wilayah Kalimantan Selatan yang sangat menguasai literatur-literatur Syi'ah dalam bahasa Arab seperti Tafsir al-Mizan karya Thabathaba'i, Usbul Madz̧bab Syi'ah alImamiyah Itsna 'Asyariyah karya al-Qifari,Yawmun Ghadir Khum karya Abdullah Alaidrus. Ia bisa dikatakan sebagai idelog Syi'ah yang diikuti pendapatnya, dipatuhi segala nasehatnya dan ditaati semua kebijaksanaannya bagi kalangan Syi'ah di Kalimantan Selatan pada umumnya, Rantau pada khususnya. Hal itu tampak pula, pada atribut-atribut yang ada di dalam rumahnya yang penuh dengan suasana berbau Syi'ah, seperti: Gambar Sayyidina Ali, Imam Khomeini, Silsilah Imam Dua Belas dan lain-lain. Di samping itu, ia sangat mengidolakan tokoh-tokoh dari kalangan Ahlul Bait dengan sepenuh jiwa, raga dan keyakinan.

Begitulah pendirian Habib Husein al-Habsyi sebagai ideolog Syi'ah Kalimantan Selatan yang sangat berpengaruh bagi penganut Syi'ah lainnya terutama bagi kalangan mudanya yang masih membutuhkan bimbingannya. Namun sayang tokoh besar ini beberapa waktu yang lalu telah meninggal dunia mendahului kita, disaat kita masih membutuhkan segala nasehat, binaan dan bimbingannya.

\section{Amuntai}

Amuntai sekitar $300 \mathrm{Km}$ dari Banjarmasin, salah satu daerah santri juga sebagaimana Martapura. Di sini, dahulu KH. Idcham Chalid (almarhum) bahkan Indonesia, menghabiskan masa kecil dan remaja bersama keluarganya. Daerah ini, merupakan basis NU kedua sesudah Martapura yang sangat kuat memegang ke-Sunniannya.

Kemunculan Syi'ah di sini, berbeda dengan daerah-daerah Kalimantan Selatan lainnnya. Ia merupakan jaringan Syi'ah dari Kalimantan Timur karena dikenalkan oleh perantau-perantau warga Amuntai dari Balikpapan dan Samarinda ketika mereka mudik hari Raya. Sekitar tahun 1990-an komunitas Syi'ah terbentuk dan sudah mempunyai majlis untuk melaksanakan amalanamalan rutin ritual Syi'ah dua kali seminggu, malam Rabu dan malam Jum'at yang dipimpin ustadz Abdurrahman. Menurut Wahyudiannoor bahwa Habib

23Wawancara dengan Nur Effendy, 20 April 2014.

24 Wawancara dengan H. Yusuf Hifni, 21 April 2014. 
Ahmad al-Habsyi salah satu pembina ABI Kalimantan Timur sering berkunjung ke daerah ini untuk melakukan pembinaan.

Suatu waktu, pernah Syi'ah di Amuntai ini yang tepatnya beralamat di Kampung Babirik dicurigai MUI (Majelis Ulama Indonesia) cabang Amuntai sebagai kelompok sesat. Lantas mereka memprakarsai untuk mengadakan dialog terbuka tentang ajaran Syi'ah dengan mengundang ulama dari pesantren dan ulama dari berbagai ormas Islam (NU dan Muhammadiyah) tak terkecuali pihak Syi'ah sendiri. Kebetulan saat itu, sedang berkunjung Habib Husin alKaff, salah seorang tokoh Syi'ah dari Jawa. Dialah kemudian didaulat untuk mewakili Syi'ah dalam forum dialog MUI Amuntai. Cukup lama perdebatan terjadi, dari satu ulama ke ulama lainnya dan Habib Husin al-Kaff yang banyak menjadi sasaran tembak. Habib Husin dengan sabar dan tenang menjawab satu persatu baik berupa pertanyaan, kritik, gugatan maupun tuduhan dan hujatan dengan pengetahuannya yang sangat luas. Setelah forum menimbang sana-sini dari berbagai argumen yang diajukan, pada akhirnya forum menyimpulkan hasil dialog adalah Syi'ah tidak termasuk aliran sesat. ${ }^{25}$

Seusai pernyataan MUI Amuntai bahwa Syi'ah tidak sesat, maka merekapun semakin bebas mengekspresikan ke-Syi'ahannya pada khalayak umum tanpa ada rasa was-was dan takut lagi. Namun sayang, kata Wahyudiannoor, saat Syi'ah makin berkembang, justru pimpinannya, ustadz Abdurrahman kemudian pindah rumah ke Jawa sehingga tidak terpantau lagi keberadaannya kini. Apakah mengalami kemajuan ataukah kemunduran?

\section{Batulicin}

Batulicin sekitar $360 \mathrm{Km}$ dari Banjarmasin, ia merupakan daerah pemekaran dari Kabupaten Kotabaru. Penduduk daerah ini terdiri dari berbagai suku yakni Bugis, Banjar, Dayak, Jawa, Madura dan lain-lain, tetapi yang dominan adalah suku Bugis.

Syi'ah muncul di sini sekitar tahun 2000-an, dibawa oleh Habib Muhammad al-Idrus dari Banjarmasin saudara dari Habib Sulaiman al-Idrus. Ia salah seorang Habib dan ulama sekaligus pedagang kembang terkenal di Batulicin, baik di mata kalangan Syi'ah sendiri maupun kalangan Sunni. Ia juga alumni pondok pesantren YAPI Bangil dan salah satu pengurus ABI Kalimantan Selatan. Ia membuka majlis di rumahnya sekitar pasar Batulicin, untuk umum yang sering dihadiri oleh ratusan orang lebih dari berbagai pelosok daerah Batulicin (Satui, Sungai Danau, Angsana, Sebamban dan Pagatan) dan Kotabaru. Majlisnya juga berfungsi untuk melaksanakan kegiatan-

25Wawancara dengan Wahyudiannoor 30 April 2014. 
kegiatan ABI termasuk melakukan amalan rutin ritual Syi'ah dua kali seminggu, malam Rabu dan malam Jum'at. ${ }^{26}$

\section{Kotabaru}

Kotabaru adalah ibukota Pulau Laut yang jaraknya dari Banjarmasin sekitar $400 \mathrm{Km}$. Wilayahnya terbagi dua, ada yang berada di daratan Kalimantan, ada yang berada di pulau tersendiri yang dipisahkan oleh Selat Laut.

Syi'ah tumbuh di daerah ini, beriringan dengan pertumbuhan Syi'ah di Tanahbumbu sekitar tahun 2000-an. Mengapa begitu ? Karena penganut Syi'ahnya memang kebanyakan dari jama'ah majlis Habib Muhammad al-Idrus. Mereka aktif mengikuti kegiatan-kegiatan Syi'ah yang dilakukan Habib Muhammad al-Idrus, baik ketika di Batulicin maupun ketika Habib mengunjungi mereka sebagai agenda rutin. ${ }^{27}$

\section{Tantangan and Respon}

Syi'ah di Kalimantan Selatan adalah Syi'ah Ja'fariyah (Imamiyah Itsna 'Asyariyah seperti di Iran), yang umumnya tergabung dalam organisasi ABI (Ahlul Bait Indonesia) daripada IJABI (Ikatan Jama'ah Ahlul Bait Indonesia (mereka tidak memakai kata Syi'ah dalam pembentukan organisasinya). Mungkin hal ini terjadi, karena tokoh-tokoh Syi'ah di sini kebanyakan dari keluarga Ahlul Bait, hanya beberapa orang yang bukan dari kalangan Habaib seperti Wahyudiannoor dan A. Busyairi Ali. Apalagi orang yang mendirikan IJABI adalah Jalaluddin Rahmat, meskipun mereka kagumi, tetapi kurang disenangi kebanyakan masyarakat Sunni di sini, bahkan MUI wilayah Kalimantan Selatan (masa KH. Asywadie Syukur, almarhum) pernah menolak kedatangannya.

Habib Ali memperkirakan penganut Syi'ah di Kalimantan Selatan antara 3000-4000 orang yang terdiri dari para Masyayikh (para pimpinan yang menguasai ritual Syi'ah), Ustadz (sebutan untuk para intelektual Syi'ah), Tasyayyu (penganut kuat Syi'ah) dan Mubibbin (simpatisan Syi'ah). Ini terlihat, ketika pelaksanaan acara peringatan Asyura yang rutin setiap tahun secara bergiliran dipusatkan di Banjarmasin dan Banjarbaru, dihadiri oleh hampir 5000-an orang, sehingga majlis-majlis dan yayasan-yayasan yang ada sudah tidak bisa menampung lagi. Beberapa tahun terakhir ini selalu dilaksanakan di tempat yang lebih luas yakni Aula Gedung RRI di Banjarmasin atau Gedung

\footnotetext{
26Wawancara dengan Wahyudiannoor, 2 Mei 2014.

27Wawancara dengan Wahyudiannoor 2 Mei 2014.
} 
Serbaguna Unlam di Banjarbaru yang punya kapasitas memadai untuk menampung orang lebih dari 6000-an. Apalagi peringatan Asyura di Kalimantan Selatan, tidak bagi “orang dalam”(tuan rumah Syi'ah Kalimantan Selatan belaka), tetapi juga dihadiri oleh penganut Syi'ah dari Kalimantan Tengah. Bukan saja terbatas pada penganut Syi'ah dan simpatisannya, melainkan juga mengundang kelompok lain, kalau boleh diurutkan terdiri dari para habaib, ustadz, intelektual, dosen muda, ormas Islam, aktivis mahasiswa dan kalangan LSM.

Hari Asyura diperingati umat Syi'ah sebagai hari yang sangat bersejarah, mengenang pembantaian terhadap Saidina Husein cucu Rasulullah Saw oleh tentara Yazid bin Mu'awiyah yang dipimpin al-Hajjaj di padang Karbala. Peristiwa ini mereka peringati dalam suasana duka yang mendalam, mereka berpuasa 2 hari tanggal 9 dan 10 Muharram, meskipun sebatas menahan haus sebagai merasakan bagaimana kehausan Saidina Husein sekeluarga ketika menghadapi perang yang sangat tidak berimbang. Dari peringatan ini kata Habib Ali diharapkan dapat menumbuhkan kecintaan yang mendalam terhadap Ahlul Bait sekaligus menjadi spirit dalam perjuangan membela Syi'ah sebagai keyakinan yang tidak salah.

Prosesi peringatan Asyura biasanya dimulai dengan membaca surah alFatihah. Kemudian dilanjutkan dengan pembacaan kalam ilahi yang dibawakan oleh seorang qari yang suaranya merdu dan syahdu. Selanjutnya, sambutansambutan dari ketua panitia sampai ketua ABI wilayah Kalimantan Selatan yang menyampaikan selamat datang kepada segenap undangan, ucapan terimakasih atas segala bantuan baik berupa materi, tenaga maupun pikiran, dan permohonan maaf jika ada kesalahan dan kekeliruan dari mulai proses perencanaan sampai pelaksanaan. Seterusnya, ceramah sekitar bikmah Asyura yang disampaikan oleh seorang habaib atau ulama baik dari Kalimantan Selatan sendiri maupun mengundang dari luar, entah dari Kalimantan lainnya atau dari Jawa. Berikutnya, lalu melantunkan Makbtam yakni nyanyian duka cita mendalam dari syair-syair yang bernada sedih dari bahasa Arab atau terjemahan yang dilakukan oleh beberapa penyanyi dengan penuh penghayatan dan ratapan. Lalu, seterusnya pembacaan Makbtal yakni semacam penyampaian ceritera secara kronologis perjalanan Saidina Husein dari tanggal 1 sampai 10 Muharram, sehingga ia menjadi syahid bersama sebagian besar keluarga dan pengikut setianya di padang Karbala yang kering dan tandus. Hal ini, biasanya dibawakan oleh orang yang pandai berceritera, dengan artikulasi yang jelas, aksentuasi dan intonasi yang indah, retorika yang cantik dan ekpressi dengan 
mimik yang elok dan mempesona. Terakhir, adalah pembacaan do'a yang dipimpin seorang habib atau ulama sepuh (Masyayikh). Sesudah do'a langsung acara ditutup dengan membaca hamdalah (alhamdulillah) secara serentak dan kemudian bubar.

Kemudian, Habib Ali mengatakan Syi'ah di sini perkembangannya cukup pesat, walaupun ada pula yang mengalami penurunan. Sekitar tahun 1980-1990-an, pada mulanya hanya ada seputar Banjarmasin, itupun hanya di lingkungan kampus Unlam terutama di Fakultas Hukum, Ekonomi dan SosialPolitik. Lantas sekitar tahun 1990-2000-an sudah berkembang merambah daerah Martapura, Barabai dan Rantau dengan bertumbuhnya beberapa majlis dan yayasan. Kemudian, sekitar tahun 2000-sekarang berkembang lagi ke wilayah Banjarbaru, Amuntai, Batulicin dan Kotabaru, dengan beberapa tambahan berdirinya majlis, yayasan dan institusi gerakan lain yang baru, meskipun terdapat satu daerah yakni Barabai yang sudah tidak terdengar lagi burinik (suara)-nya, juga satu yayasan yang bubar yakni yayasan ar-Ridha. Selanjutnya, Habib Ali melanjutkan pembicaraan, katanya meskipun aktivitas kalangan Syi'ah Kalimantan Selatan masih dominan baru bersifat ritual, tetapi tak bisa disangkal sudah ada pula gerakan intelektual, advokasi dan pemberdayaan. Kesemuanya mempunyai plus-minusnya masing-masing, tetapi sebenarnya justru saling mengisi satu sama lain. Ada sebagian yang mengatakan gerakan intelektual lebih baik dan efektif, karena dengan melalui diskusi, dialog dan konsultasi yang sedikit intens akan dapat dan cepat diterima akal sehat bagi si pendengar atau si peminat, apalagi jika sasarannya memang kalangan mahasiswa dan kaum terpelajar yang suka dengan pemikiran logis, rasional dan ilmiah. Sebagian lain, berpendapat bahwa gerakan ritual berupa bimbingan ibadah dan ajaran do'a-do'a para Imam yang sesuai dengan keyakinan Syi'ah, merupakan kegiatan yang baik dan tepat untuk menanamkan dan memantabkan keyakinan, terutama bagi pendengar dan peminat yang sedang goyah dan tidak punya pegangan hidup. Sedangkan, Habib Ali lebih memilih gerakan advokasi dan pemberdayaan sebagai kegiatan yang terbaik tanpa harus melihat latar belakang apapun bagi mereka yang dibela, semata-mata niat tulus lillahi ta'ala dan demi nilai kemanusiaan universal. Agak sedikit berbeda dengan Wahyudiannoor, menginginkan kontekstualisasi ajaran Syi'ah ke dalam budaya lokal Banjar yang adiluhung. Jika masyarakat Banjar begitu kuat budaya mistik atau kebatinannya, alangkah sangat baiknya jika Syi'ah lebih mengedepankan dimensi irfan daripada yang lainnya. Artinya, bukan untuk meninggalkan dimensi ajaran Syi'ah yang lain, karena itu juga penting, hanya bagaimana 
dimensi irfan dijadikan sebagai angle, biar mudah ketemu dan berpadu ajaran Syi'ah dengan budaya Banjar dalam ruang batin manusia Banjar. ${ }^{28}$

Argumen-argumen pilihan gerakan di atas, memang tidak bisa dipungkiri akan saling berkompetisi dan berkontestasi di dalam ruang publik gerakan Syi'ah di Kalimantan Selatan, tetapi tentu saja, tidak sampai membuat mereka saling bersengketa, sebaliknya justru saling bersekutu untuk meraih rahmat Allah sebanyak-banyaknya. Bukankah sabda Rasulullah Saw perbedaan itu rahmat asal berlomba demi kebaikan dan saling tolong-menolong dalam ketakwaan.

Untuk memperkuat seluruh gerakan yang ada, Syi'ah Kalimantan Selatan sering mendatangkan dan kedatangan tokoh-tokoh Syi'ah dari luar (luar Kalimantan Selatan dan luar negeri). Seperti mereka mengundang Habib Thaha dari Semarang sebagai alumni Universitas Qum, Iran dan beberapa intelektual Syi'ah dari Bandung adalah bertujuan untuk memperkuat dan memperkaya ranah gerakan intelektual. Sedangkan mengundang aktivis Syi'ah Jakarta dan kedatangan aktivis Syi'ah Iran, Amar al-Hakim Hujjatul Islam al-Hakim adalah bertujuan untuk memperkuat dan memperkaya gerakan advokasi dan pemberdayaan. Sementara, kedatangan tokoh Syi'ah dari Malaysia dan Zahir Yahya dari Bangil, Jawa Timur adalah bertujuan untuk memperkuat dan memperkaya gerakan ritual yang selama ini sebenarnya sudah terlalu dominan.

Keadaan Syi'ah yang kondusif ini di Kalimantan Selatan, bukan berarti tanpa tantangan. Menurut Habib Ali ada 2 tantangan yang harus dicermati, mungkin tidak hanya bagi Syi'ah di Kalimantan Selatan, tetapi juga, bagi Syi'ah seluruh Indonesia yakni adu domba Syi'ah-Sunni dan hujatan kaum Wahabi/Salafi.

\section{Adu Domba Syi'ah-Sunni}

Ada skenario besar kata Habib Ali yang sedang dilakukan Kapitalisme global yang dikepalai Amerika Serikat untuk menghancurkan umat Islam. Mereka sudah sangat paham bagaimana cara menghancurkan sendi-sendi kekuatan Islam. Bukan langsung diserang secara langsung dan memerangi suatu negara atau kelompok Islam, melainkan masuk ke dalam secara halus, lantas melakukan adu domba antar mereka, saat ini yakni adu domba antara Syi'ah dan Sunni.

Adu domba ini sudah berhasil mereka lakukan pada beberapa negara Islam yang sedang bertikai seperti negara Mesir, Irak, Syiria, Pakistan dan Afganistan. Beberapa negara yang disebut barusan sampai sekarang masih

28Wawancara dengan Wahyudiannoor, 21 April 2014. 
bertikai seperti tanpa kunjung berhenti, belum ada yang mampu mendamaikan dengan tuntas. Tidak ada lagi persatuan, sudah hilang rasa kekeluargaan, pupus sudah kebersamaan, tanpa ada keamanan, kenyamanan dan kesejahteraan, yang ada hanya pertengkaran, permusuhan, kebencian, dendam kesumat, kepedihan, penderitaan dan kesengsaraan.

Habib Ali mengingatkan, kalau kita (Syi'ah-Sunni) tidak hati-hati, negara kita Indonesia, termasuk Kalimantan Selatan akan menjadi giliran berikutnya proyek adu domba. Gejala ini sudah nampak di mata kita, ketika kita mencermati banyaknya kepentingan Amerika Serikat di negeri ini. Apalagi jika melihat perke mbangan ekonomi dunia ke depan yang kemungkinan akan berpusat di Asia-Pasifik, tidak lagi di Timur Tengah, negara Indonesia menjadi elemen penting dari dinamika tersebut.

Untungnya, sejarah hubungan Syi'ah-Sunni di Indonesia, termasuk di Kalimantan Selatan sangat baik, bahu-membahu dalam mendakwahkan Islam tanpa ada ego aliran satu sama lain sehingga jauh dari tradisi pertikaian sebagaimana di kawasan Islam lain. Meskipun pada awal kedatangan Islam, pernah terjadi sedikit konflik karena memang tetap ada kompetisi dan kontestasi antara Syi'ah dan Sunni, tetapi lebih banyak kerjasama dan kebersamaannya. Konflik yang terjadi tidak pernah berkepanjangan, hanya sesaat, selebihnya adalah saling memberi dan menerima, saling mengambil dan memperkaya satu sama lain sehingga hampir sulit membedakan antara keduanya ibarat dua sisi mata uang dalam kesatuan bulatan. Pendek kata, antara Syi'ah dan Sunni di sini banyak persamaannya atau titik temunya seperti samasama senang ziarah kubur, tawassul, maulud, mencintai Rasulullah Saw dan keluarganya dan lain-lain, walaupun tidak membantah terdapat pula perbedaanperbedaan.

Pengalaman sejarah yang positif ini, memang bisa menjadi modal dasar membangun kerukunan antara Syi'ah dan Sunni. Namun hanya berbekal itu masih tidak cukup untuk menjalin hubungan yang erat tak tergoyahkan, harus didukung dengan lebih banyak lagi membangun hubungan-hubungan baru. Tidak sekadar dengan dialog-dialog wacana belaka, atau kebersamaan menggarap program, tetapi juga kerjasama-kerjasama karya yang terkait memperjuangkan nilai-nilai kemanusiaan dan ketuhanan dalam tarikan satu nafas.

Habib Ali meyakini Syi'ah-Sunni di daerah ini tidak akan mudah terprovokasi apalagi konflik, walaupun potensi itu ada, karena Syi'ah di sini dan daerah lainnya di Indonesia, tidak akan membangun tempat ibadah sendiri yang 
ekslusif, melainkan hanya ikut tempat ibadah yang ada dan tidak akan merebutnya bahkan ikut mempertahankannya dengan cara ibadah yang sama. Demikian juga dengan lembaga pendidikan yang dimiliki baik berupa pesantren, madrasah maupun sekolah, tidak akan sampai melahirkan Imam seperti di Iran, Irak, Syiria dan Lebanon. Artinya, tidak berpotensi untuk menyebarkan perbedaan-perbedaan, justru lebih mengedepankan persamaanpersamaan. Sebaliknya juga, Habib Ali percaya NU (Nahdlatul Ulama) yang menjadi refresentasi Sunni Indonesia, termasuk Kalimantan Selatan sudah jauhjauh hari mengantisipasi gejala ini. Dia berharap banyak NU wilayah Kalimantan Selatan mampu menjadi saudara kandung Syi'ah yang baik, tidak terpancing oleh isu-isu negatif dan provokasi destruktif yang sengaja dilontarkan orang yang tidak bertanggung Jawab untuk memancing di air keruh. Lebih dari itu, Syi'ah ingin ada dialog yang intensif, reguler dan permanen dengan NU, untuk membangun kesepahaman dan mengenal ajaran satu sama lain. Syukur-syukur setelah itu ada semacam program kerja bersama dalam memperjuangkan nilai-nilai kemanusiaan seperti mengentaskan kemiskinan, memperbaiki kualitas pendidikan, membela mereka yang tertindas, melawan penguasa diktator, menggelorakan keadilan, kesejahteraan dan akhlakul karimah.

\section{Hujatan Kaum Wahabi/Salafi}

Sebenarnya tantangan yang kedua ini merupakan bagian tak terpisahkan dari tantangan yang pertama. Habib Ali mengatakan bahwa Wahabi/Salafi dipakai Amerika Serikat untuk proses eskalasi adu domba Syi'ah-Sunni, karena mereka sudah lama memusuhi Syi'ah dan terbiasa melakukan tindakan kekerasan atas nama agama. Sekitar Februari 2014 yang lalu kelompok ini semacam melakukan sosialisasi dan kampanye tentang kesesatan Syi'ah dengan acara bedah buku "Mengenal \& Mewaspadai Penyimpangan Syi'ah di Indonesia" di Masjid Hasanuddin HM. Jl. H. Hasan Basri (Kayutangi), Banjarmasin. Di sana, mereka melontarkan beberapa penyimpangan yang dilakukan Syi'ah seperti soal penyimpangan faham tentang orisinalitas Al-Qur'an, penyimpangan tentang Ablul Bait Rasul, pengkapiran sababat Nabi, pengkapiran umat Islam lain, penyimpangan faham tentang kedudukan Imam Syi'ah dan penyimpangan tentang hokum nikah Mut'ah yang menurut mereka salah, kemudian mereka mengaku didukung oleh pendapat Hamka (tokoh Muhammadiyah) dan KH. Hasyim Asy'ari (tokoh NU). ${ }^{29}$ Lebih dari itu, menurut HM. Yusuf (dosen F. Tarbiyah IAIN Antasari) yang sering

${ }^{29}$ Tim MUI Pusat, Mengenal \& Mewaspadai Penyimpangan Syiah di Indonesia, Jakarta: Formas,2013, hlm. 7. 
salat berjama'ah di masjid-masjid sekitar kota Banjarbaru yang dikuasai kaum Wahabi/Salafi, para da'i mereka tidak henti-hentinya menghujat kesesatan Syi'ah, bahkan baru-baru ini mereka memperbanyak sendiri buku "Mengenal \& Mewaspadai Penyimpangan Syi'ah di Indonesia" dengan mencetaknya secara massif dan disebarkan ke berbagai kalangan. ${ }^{30}$

Habib Ali menanggapi kejadian ini dengan sikap tenang sekali, seolaholah tidak merasa terganggu dengan berbagai hujatan tersebut. Katanya; tak perlu digubris kicauan keras mereka anggap saja angin lalu atau seperti ungkapan pepatah biarkan anjing menggonggong kafilah tetap berlalu. Karena mereka juga tak bisa diajak diskusi dan dialog secara baik-baik, ingin mereka kita harus mengikuti dan mengamini segala yang mereka katakan, tak ada ruang untuk membantah dan membela diri. Saat ini, kita cukup berdiam diri saja tak usah terpancing provokasi mereka yang penting kita terus berkarya menunjukkan segala pengabdian kita untuk Tuhan dan kemanusiaan. Apalagi pengurus pusat $\mathrm{ABI}$ organisasi kami sudah menerbitkan sebuah buku pada Desember 2012 yakni Buku Putih Mazhab Syi'ah, yang diberi kata pengantar oleh Bapak Quraish Shihab dengan sangat baik, dan isinya sendiri menjawab seluruh tuduhan dan hujatan yang selama ini dilontarkan oleh pihak-pihak yang tidak bertanggung-jawab.

\section{Penutup}

Dari uraian di atas dapat disimpulkan bahwa Syi'ah adalah mazhab terbesar kedua setelah Sunni di dalam lingkungan umat Islam, yang mencakup tak kurang dari 300 juta orang diberbagai belahan dunia termasuk di Indonesia yang di dalamnya ada Kalimantan Selatan. Lebih dari itu, Syi'ah Ja'fariyah diakui sebagai salah satu mazhab sah dalam Islam oleh para ulama dari berbagai kelompok dan berbagai Negara Islam sepanjang sejarah agama ini. Demikian pula, kontribusinya terhadap kebudayaan dan peradaban Islam juga sama sekali tak bisa diabaikan.

Syi'ah hadir di Kalimantan Selatan sejak masuknya Islam di daerah ini, bersama-sama berdampingan dengan kalangan Sunni. Wajar, jika sampai sekarang masih ada dan mulai semakin berkembang, meskipun dahulu mungkin Syi'ah Zaidiyah, sedangkan yang sekarang Syi'ah Ja'fariyah.

Pertumbuhan dan perkembangan Syi'ah Ja'fariyah di sini tidak sematamata di kota Banjarmasin, tetapi sudah meluas ke Banjarbaru, Martapura, Rantau, Amuntai, Batulicin dan Kotabaru dengan jumlah penganut/pengikut

30Wawancara dengan H.M. Yusuf, 5 Mei 2014. 
mencapai kira-kira 3000-4000 an orang yang terdiri dari Masyayikh, Ustadz, Tasyayyu' dan Muhibbin dan mereka kebanyakan tergabung dalam organisasi ABI daripada IJABI, yang keduanya sudah menjadi ormas keagamaan resmi sebagaimana organisasi NU dan Muhammadiyah. Demikian juga, dengan pertumbuhan dan perkembangan lembaga-lembaga baik berupa yayasan maupun majlis yang melakukan berbagai kegiatan dan gerakan. Meskipun tampak kegiatan ritual lebih dominan, tetapi kegiatan lainnya juga cukup beragam seperti gerakan pemberdayaan ekonomi, advokasi, sosial dan pendidikan yang pada saatnya nanti akan saling menyokong satu-sama lain, menjadi semacam satu-kesatuan gerakan.

Memang gerakan Syi'ah Ja'fariyah di Kalimantan Selatan, tidak sunyi dari tantangan baik berupa hujatan, tuduhan maupun kecaman dan stigmatisasi terutama dari kelompok Wahabi/Salafi. Namun, karena para tokohnya tidak mudah terpancing untuk membalas dengan cara yang dilakukan lawanlawannya, melainkan menghadapi mereka dengan sabar, tenang dan cerdas, jauh dari sikap keras dan kasar. Lebih dari itu, seperti Habib Sulaiman al-Idrus, Habib Muhammad al-Idrus, Habib Abdullah al-Habsyi dan Habib Husein alHabsyi (almarhum) adalah Masyayikh-Masyayikh yang sangat kharismatis, dihormati pihak kawan dan pihak lawan, mereka bisa berinteraksi dengan siapapun tanpa takut kehilangan identitas diri dan tercerabut dari akar tradisi kesyi'ahannya. Demikian juga, dengan Busyairi Ali dan Habib Ali sebagai Ustadz-Ustadz cerdas dan familiar yang bisa diterima oleh berbagai kalangan yang berada di lingkungannya masing-masing. Ditambah lagi, Wahyudiannoor, seorang aktivis yang punya obsesi untuk melakukan kontekstualisasi doktrin Syi'ah dengan kebudayaan Banjar. Tentu kesemuanya ini, akan membuat Syi'ah Ja'fariyah yang tergabung dalam organisasi ABI atau IJABI secara perlahanlahan akan diterima baik oleh masyarakat Banjar yang pada umumnya penganut/pengikut Sunni. Semoga perjalanan sejarah akan membuktikannya.

\section{Daftar Pustaka}

Ad-Dakhil, Ali Muhammad Ali, Aimmatuna, Beirut Lebanon: Dar al-Murtadla, 1982.

Adib, Muhammad Husain, Sekilas Mengenal Empat Belas Ma'sum, Qum,Iran: Yayasan Imam Ali as, 1973.

Ali, Busyairi, Nikah Mut'ah, Halal atau Haram, Banjarmasin: Ar-Risalah Islamic Centre Foundation, 2012. 
Anshary, Hafiz, Islam di Selatan Borneo sebelum Kerajaan Banjar, Orasi Ilmiah, Banjarmasin: IAIN Antasari, 2002.

Azra, Azyumardi,'Interaksi dan Akomadasi Islam dengan Budaya Melayu Kalimantan", makalah Simposium Nasional, 1996.

Azra, Azyumardi, Jringan Ulama Nusantara, Bandung: Mizan, 1994.

Hadariansyah, Pemikiran-Pemikiran Teologi, Dalam Sejarah Pemikiran Islam, Banjarmasin: Antasari Press, 2013.

Hasan, Ilyas, Rasul Ja'farian, Sejarah Islam, Study Kritis Sejak Wafat Nabi Saw Hingga Runtubnya Bani Umayyah, Jakarta: PT. Lentera Basritama, 2004.

Isa, Ahmadi,"Perkembangan Tasawuf di Kalimantan Selatan", tabloid Serambi Ummah No.045, 8-14 September 2000.

Khumaini, Imam, Al-Ahkam al-Muyassarah, Qum Iran: Dar al-Tiyar al-Jadid, 1982

Mughniyah, Muhammad Jawad, Fiqh al-Imam Ja'far al-Shadiq, Beirut: Dar al-Ilmi li al-Malayin, 1966.

Nasution, Harun, Teologi Islam, Jakarta: UI-Press, 1986.

Ras, J.J, Hikajat Bandjar; A Study in Malay Historiography, The Hague: Martinus Nijhoff, 1968.

Saleh, Idwar, Bandjarmasin, Banjarbaru: Unlam, 1982.

Sofyan, Dicky, Peny., Sejarah \& Budaya Syi'ah di Asia Tenggara, Yogyakarta: Sekolah Pascasarjana UGM, 2013.

Tim ABI, Buku Putih Marhab Syi'ah, Jakarta: DPP ABI,2012.

Tim ICRO \& Tim ACCRoS,

Tim MUI Pusat, Mengenal \& Mewaspadai Penyimpangan Syi'ah di Indonesia, Jakarta: Formas,2013.

Tim Peneliti F. Syari'ah, Gerakan Syi'ah di Kalimantan Selatan, Banjarmasin: Puslit IAIN Antasari, 2001.

Tim Penyusun, Ensiklopedi Islam, jilid I, Jakarta: PT. Ichtiar Baru van Hoeve,2005.

Usman, Gazali, Kerajaan Banjar, Sejarah Perkembangan Politik, Ekonomi, Perdagangan dan Agama, Banjarbaru: Unlam Press, 1998. 